Tropical Journal of Pharmaceutical Research September 2021; 20 (9): 1827-1832

ISSN: $1596-5996$ (print); 1596-9827 (electronic)

(C) Pharmacotherapy Group, Faculty of Pharmacy, University of Benin, Benin City, 300001 Nigeria.

\title{
Metformin promotes apoptosis of A549 cells via regulation of p-AMPK protein expression, bax/bcl-2 ratio and ROS levels
}

\author{
Ziying Yu ${ }^{1}$, Fengtao Liu², Xiaoli Zhang ${ }^{3 *}$ \\ ${ }^{1}$ Department of Emergency, The First Affiliated Hospital of University of South China, ${ }^{2}$ Center of Functional Laboratory, \\ Hengyang Medical College, The University of South China, ${ }^{3}$ Department of Pathology, The First Affiliated Hospital of University \\ of South China, Hengyang 421001, Hunan Province, China
}

*For correspondence: Email: zxldyc2020@163.com

Sent for review: 31 May 2021

Revised accepted: 16 August 2021

\begin{abstract}
Purpose: To investigate the influence of metformin on apoptosis of pulmonary carcinoma cells (A549), and the associated mode of action.

Methods: Pulmonary carcinoma cells in logarithmic growth phase were treated with graded concentrations of metformin, and the anti-proliferative and apoptotic effects of the drug were measured using MTT assay and flow cytometry, respectively. The levels of reactive oxygen species (ROS) in A549 cell suspension were determined with 2, 7- dihydrodichlorofluorescein diacetate (DCFH-DA) assay. The expression levels of phosphorylated AMP-activated protein kinase ( $p-A M P K)$, mammalian target of rapamycin ( $m T O R)$, and bax/bcl-2 ratio were measured using Western blotting and real-time fluorescence quantitative polymerase chain reaction (qRT-PCR).

Results: Metformin significantly promoted A549 cell apoptosis, but suppressed its proliferative potential in a dose- and time-based fashion. The levels of ROS, superoxide anion and MDA in A549 cells were significantly and dose-dependently increased by metformin $(p<0.05)$. Moreover, metformin markedly upregulated the mRNA and protein expressions of $p$-AMPK as well as bax/bcl-2 ratio, but had no impact on the expression level of mTOR $(p<0.05)$.

Conclusion: Metformin promotes apoptosis in A549 cells via regulation of p-AMPK protein expression, bax/bcl-2 ratio, and ROS levels, and hence may play a role in lung cancer therapy.
\end{abstract}

Keywords: Apoptosis, Lung cancer, Metformin, Proliferation, Reactive oxygen species

\begin{abstract}
This is an Open Access article that uses a funding model which does not charge readers or their institutions for access and distributed under the terms of the Creative Commons Attribution License (http://creativecommons.org/licenses/by/4.0) and the Budapest Open Access Initiative (http://www.budapestopenaccessinitiative.org/read), which permit unrestricted use, distribution, and reproduction in any medium, provided the original work is properly credited.
\end{abstract}

Tropical Journal of Pharmaceutical Research is indexed by Science Citation Index (SciSearch), Scopus, International Pharmaceutical Abstract, Chemical Abstracts, Embase, Index Copernicus, EBSCO, African Index Medicus, JournalSeek, Journal Citation Reports/Science Edition, Directory of Open Access Journals (DOAJ), African Journal Online, Bioline International, Open-J-Gate and Pharmacy Abstracts

\section{INTRODUCTION}

Pulmonary carcinoma, a frequently diagnosed malignancy in clinical practice, is associated with high morbidity and mortality. According to statistics, there are over 1.2 million new cases of lung cancer annually, with more than 900,000 deaths globally. The disease seriously impacts negatively on the quality of life of patients [1]. At present, surgical resection remains the major strategy for the treatment of lung cancer. However, because the disease has an insidious onset, more than $50 \%$ of the patients usually are unable to benefit from treatment at the time of 
diagnosis. Although patients are often treated with a combination of radiotherapy and chemotherapy, the 5-year survival of lung cancer is less than $10 \%$. The combination therapy produces serious side effects, thereby necessitating the search for novel effective drugs with good prognosis and limited side effects [2].

Metformin is a commonly used hypoglycemic drug. Its hypoglycemic effect is exerted via inhibition of gluconeogenesis and glycogenolysis (glycogen breakdown), as well as stimulation of the sensitivity of peripheral tissues to insulin [3]. It has been reported that metformin significantly reduces the incidence of malignant tumor in type 2 diabetes mellitus (T2DM) patients [4]. It has also been speculated that metformin inhibits the growth of tumor cells via activation of adenosine monophosphate-activated protein kinase (AMPK) signaling pathway, as well as promotion of protein synthesis and cell apoptosis [5]. This research was carried out to determine the influence of metformin on A549 cell apoptosis, as well as the associated mode of action.

\section{EXPERIMENTAL}

\section{Materials}

Optical microscope (WMJ-9590) was obtained from Shanghai Yuguang Instrument Co. Ltd. Electronic balance (JA2603) was bought from Shanghai Precision Instrument Co. Ltd. Ultra-low temperature refrigerator (DL-86L828) was a product of Beijing Nuohuicheng Technology Co. Ltd. Flow cytometer (B5-R3-V3) was purchased from Beckman Coulter (USA). Cryogenic highspeed centrifuge (TG16G) was obtained from Changzhou Jintan Lepu Instrument Company, while carbon dioxide incubator (ZCP-270WIR) was produced by Shanghai Zhetu Scientific Instrument Co. Ltd. Electric thermostatic water bath (WB-1-15) was obtained from Shanghai Shibei Instrument Equipment Factory. Fetal bovine serum (FBS) was bought from Shanghai Huiying Biotech. Co. Ltd. Metformin was product of Sino-American Shanghai Squibb Pharmaceutical Company, while MTT solution was obtained from Beijing Zhongsheng Ruitai Technology Co. Ltd. Bax antibody was bought from Shanghai Hengyuan Biotechnology Company; bcl-2 antibody was obtained from EmMETt Technologies, while p-AMPK antibody was supplied by Xiamen Huijia Biotech. Co. Ltd.

\section{Cell line and maintenance}

The lung cancer cells (A549) were sourced from Shanghai Tongpai Biotech. Co. Ltd. The cells were cultured for $24 \mathrm{~h}$ at $37^{\circ} \mathrm{C}$ in DMEM containing FBS $(10 \%)$ and $1 \%$ penicillin/ streptomycin in a $5 \% \mathrm{CO}_{2}$ incubator. When the cells attained $85 \%$ confluency, the resultant adherent cells were trypsinized with $2 \mathrm{~mL}$ of 0.25 $\%$ trypsin, centrifuged at $1500 \mathrm{rpm}$ for $10 \mathrm{~min}$, and converted to a suspension of individual cells which were seeded in culture wells $\left(2 \times 10^{4}\right.$ cells/well; $100 \mu \mathrm{L}$ per well). On attainment of 60 $70 \%$ confluency following incubation, cells at logarithmic growth phase were incubated with varying doses of metformin for $24 \mathrm{~h}$, with metformin-free cell culture as control group.

\section{Cell proliferation assay}

The proliferative capacity of A549 cells was determined using MTT assay. The cells were seeded in 96-well plates at a density of $2 \times 10^{4}$ cells/well (100 $\mu \mathrm{L}$ per well) and cultured in DMEM for $24 \mathrm{~h}$. Varied concentrations of metformin were incubated with the cells for $72 \mathrm{~h}$, after which the cells were incubated with MTT $(0.5 \mathrm{~g} / 100 \mathrm{~mL} ; 20 \mu \mathrm{L})$ for additional $4 \mathrm{~h}$. Then, the medium was discarded, and the resultant formazan crystals in each well were solubilized in $150 \mathrm{~mL}$ of $0.1 \%$ DMSO $(150 \mathrm{~mL})$, followed by absorbance measurement at $540 \mathrm{~nm}$ in a microplate instrument. Percentage proliferative potential was measured at $24 \mathrm{~h}$ and $48 \mathrm{~h}$.

\section{Measurement of apoptotic potential}

Following 24-h culturing, cells plated in 6-well plates $\left(2 \times 10^{4}\right.$ cells/well $)$ in 6 -well plates were treated with varied concentrations of metformin, followed by further incubation for 2 days. Thereafter, the cells were rinsed in phosphatebuffered saline, and a homogenous cell suspension was produced by addition of $500 \mu \mathrm{L}$ of binding buffer. This was followed by cell staining (in a dark chamber) with V/FITC $(10 \mu \mathrm{L})$ and $5 \mu \mathrm{L}$ of PI. The degree of apoptosis was measured flow cytometrically.

\section{Determination of ROS levels}

In this procedure, A549 cells treated with varied concentrations of metformin were PBS-rinsed after they were incubated for $72 \mathrm{~h}$, followed by addition of DCFH-DA $(10 \mu \mathrm{M})$ to each well. Incubation was carried out again at $37{ }^{\circ} \mathrm{C}$ for about $35 \mathrm{~min}$, followed by PBS-rinsing and flow cytometric analysis. The level of MDA in cell suspension was assayed using commercially available kit.

\section{Assay of mRNA expressions using qRT-PCR}

Following treatment of A549 cells with graded concentrations of metformin for $48 \mathrm{~h}$, the mRNA 
expressions of p-AMPK, mTOR, bax and bcl-2 in the cells were determined with qRT-PCR. Total cellular RNA extraction was done with TRIzol reagent, followed by reverse transcription to cDNA with cDNA synthesis kits as per the manufacturer's protocol. The mRNA expression levels of the various genes were determined using Light Cycler 1536 RT-PCR equipment, with GAPDH as the house-keeping gene. Relative mRNA expressions were calculated with the $2^{-}$ $\Delta \Delta \mathrm{Ct}$ procedure.

\section{Immunoblot assay}

Total protein was extracted from cells in each group using chilled RIPA buffer laced with protease inhibitor. Following centrifugation, the protein content of each lysate was determined using the BCA procedure. Equal amounts of protein samples $(40-\mu \mathrm{g})$ were subjected to $12 \%$ SDS-PAGE, followed by electro-transfer to PVDF membranes. Thereafter, the membranes were blocked by incubation with $3 \%$ fat-free milk solution, followed by incubation at $4{ }^{\circ} \mathrm{C}$ overnight with $1^{\circ}$ antibodies for bcl-2, p-AMPK, bax, mTOR and GAPDH (all diluted 1: 800). Then, after rinsing 3 times in TBS-T, the membranes were incubated with HRP-linked $2^{\circ}$ antibody at laboratory temperature for $90 \mathrm{~min}$. Blot development was carried out using X-ray film, while ImageJ Launcher software was employed for grayscale analysis of the bands. Relative protein expression levels were calculated with reference to GAPDH which was used standard.

\section{Statistics}

Results are presented as mean \pm SEM, and they were analyzed with SPSS version 23.0. Twogroup comparison was done with $t$-test. Significant differences were assumed at $p<$ 0.05 .

\section{RESULTS}

\section{Influence of metformin on cell proliferation}

The proliferative capacity of A549 cells was markedly and time- and dose-dependently reduced by metformin ( $p<0.05$; Table 1$)$.

\section{Effect of metformin on cell apoptosis}

As shown in Table 2, exposure of A549 cells to metformin markedly enhanced apoptosis in a concentration-based fashion $(p<0.05)$.
Table 1: Effect of metformin on cell proliferation (mean \pm SEM, $n=5$ )

\begin{tabular}{lcc}
\hline Group & \multicolumn{2}{c}{ Cell survival (\%) } \\
\cline { 2 - 3 } & $\mathbf{2 4 \mathbf { h }}$ & $\mathbf{4 8} \mathbf{~}$ \\
\hline Control & $283.45 \pm 13.19$ & $687.81 \pm 30.64$ \\
Metformin (15 & $135.74 \pm 26.44$ & $520.88 \pm 35.47^{*}$ \\
$\mathrm{mM})$ & & \\
Metformin (30 & $96.48 \pm 14.86$ & $112.49 \pm 13.09^{\star}$ \\
$\mathrm{mM})$ & & \\
$F$ & 133.28 & 554.88 \\
$P$-value & $<0.001$ & $<0.001$ \\
\hline${ }^{*} P<0.05$ compared with control group
\end{tabular}

Table 2: Influence of metformin on cell apoptosis (mean \pm SEM, $\mathrm{n}=5$ )

\begin{tabular}{lc}
\hline Group & Cell apoptosis (\%) \\
\hline Control & $1.05 \pm 0.12$ \\
Metformin $(15 \mathrm{mM})$ & $14.38 \pm 2.56^{*}$ \\
Metformin $(30 \mathrm{mM})$ & $34.64 \pm 4.83^{*}$ \\
$F$ & 312.26 \\
$P$-value & $<0.001$ \\
\hline${ }^{*} P<0.05$, vs control &
\end{tabular}

\section{Impact of metformin on ROS concentrations}

The levels of ROS, superoxide anion and MDA in A549 cells were significantly and dosedependently increased by metformin treatment ( $p$ $<0.05$; Table 3).

Table 3: Comparison of levels of ROS amongst the 3 groups (mean \pm SEM, $n=5$ )

\begin{tabular}{lccc}
\hline Group & ROS & $\begin{array}{c}\text { Superoxide } \\
\text { anion }\end{array}$ & $\begin{array}{c}\text { MDA } \\
\text { ( } \begin{array}{c}\text { Mmol/mg } \\
\text { protein) }\end{array}\end{array}$ \\
\hline Control & $1.58 \pm 0.35$ & $21.62 \pm 2.44$ & $0.51 \pm 0.26$ \\
Metformin & $23.18 \pm$ & $58.69 \pm$ & $1.23 \pm 0.33^{*}$ \\
$(15 \mathrm{mM})$ & $4.36^{*}$ & $7.56^{*}$ & \\
Metformin & $145.86 \pm$ & $129.87 \pm$ & $2.58 \pm 0.29^{*}$ \\
$(30 \mathrm{mM})$ & $13.74^{*}$ & $26.81^{*}$ & \\
$F$ & 436.87 & 58.06 & 63.56 \\
$P$-value & $<0.001$ & $<0.001$ & $<0.001$ \\
\hline
\end{tabular}

${ }^{*} P<0.05$, vs control

\section{Effect of metformin on expression levels of $p$ - AMPK, mTOR, bax and bcl-2}

Metformin markedly and concentrationdependently increased the mRNA and protein expressions of $\mathrm{p}-\mathrm{AMPK}$ in A549 cells, and also increased bax/bcl-2 ratio $(p<0.05)$. However, it did not significantly alter the expression level of mTOR $(p>0.05)$. These results are shown in Table 4.

\section{DISCUSSION}

Lung cancer poses serious threat to humans. There has been a global rise in the incidence of lung cancer.

Trop J Pharm Res, September 2021; 20(9): 000 
Table 4: Effect of metformin on mRNA expressions of p-AMPK, mTOR, bax and bcl-2 (mean \pm SEM, $n=5)$

\begin{tabular}{lccc}
\hline Group & p-AMPK & mTOR & bax/bcl-2 \\
\hline Control & $0.65 \pm$ & $0.47 \pm$ & $6.98 \pm 1.03$ \\
& 0.03 & 0.07 & \\
Metformin & $0.77 \pm$ & $0.45 \pm$ & $10.14 \pm$ \\
$(15 \mathrm{mM})$ & $0.06^{*}$ & 0.05 & $1.55^{\star}$ \\
Metformin & $0.92 \pm$ & $0.43 \pm$ & $14.79 \pm$ \\
$(30 \mathrm{mM})$ & $0.04^{*}$ & 0.04 & $3.11^{*}$ \\
$F$ & 45.00 & 0.67 & 17.62 \\
$P$-value & $<0.001$ & 0.531 & $<0.001$ \\
\hline${ }^{*} P<0.05$, vs control & &
\end{tabular}

In China, lung cancer-related morbidity and mortality rank first among malignant tumors, with lung adenocarcinoma being the most common pathological subtype of non-small cell lung cancer (NSCLC). Lung adenocarcinoma, which occurs mainly around the lungs, is usually seen in patients who are habitual smokers, and it is the predominant cancer type in young women and in Asians. Patients with lung cancer often miss treatment at the time of diagnosis because of the insidious nature of the disease [6].

At present, the main clinical treatment for lung cancer is combination of surgery and chemoradiotherapy. Although the treatment of lung cancer has seen some improvements over the years, the overall prognosis remains poor, thereby necessitating the search for novel and effective drugs with less side effects [2].

Metformin is an antidiabetic drug which has shown great promise in the treatment of malignant tumors. It lowers blood glucose by stimulating the sensitivity of peripheral tissues to insulin [7]. Reports have implicated metformin in the treatment of polycystic ovary syndrome [8]. Studies have shown that T2DM patients treated with metformin medication responded better to chemotherapy than those placed on sulfonylureas [9]. It has been speculated that metformin may significantly reduce the incidence of cancer and cancer-related mortality [9].

An equilibrium between cell proliferation and apoptosis is vital for regulation of cell growth. Apoptosis refers to autonomic programmed cell death informed by gene regulation. Being the main mechanism of anti-tumor drugs, apoptosis is crucial for the maintenance of stable internal microenvironment of normal cells [10]. The gene bcl-2 belongs to the bcl-2 family of proteins that control cell death via inhibition (anti-apoptosis) or induction (pro-apoptosis). It was first isolated from human follicular lymphoma. It participates in tumorigenesis by making the immune system lose its ability to kill abnormal cells [11].

In humans, the bcl-2-associated $X$ protein (bax), also known as bcl-2-like protein 4 , is encoded by the bax gene. It antagonizes the inhibitory effect of bcl-2 protein on apoptosis. Studies have shown that the upregulation of bax protein expression markedly stimulates cell apoptosis, while inhibiting cell proliferation. In addition, bax prevents lymphatic metastasis of tumor cells [12]. It has been established that bax/bcl-2 ratio is closely related to apoptosis or survival of cancer cells [13]. The results obtained in the present research demonstrated that metformin markedly promoted A549 cell apoptosis, but inhibited its proliferation.

Under normal physiological conditions, there is a cellular balance between ROS production and their clearance. When the tissues are stimulated, the production of ROS is markedly enhanced. Increases in ROS over and above normal levels damage cell structure. Moreover, ROS act as second messengers in the regulation of cell proliferation and apoptosis [14-16].

Adenosine monophosphate-activated protein kinase (AMPK) is an energy signal-sensing protein ubiquitously expressed in cells of body tissues where it participates in the maintenance of cell homeostasis. On activation by sugar, hypoxemia or oxidative stress, AMPK activates downstream signaling pathways, thereby keeping intracellular energy level constant, while maintaining normal cell division cycle [17-19].

Adenosine monophosphate-activated protein kinase (AMPK) has several receptor-linked signaling pathways such as mTOR signaling pathway, bcl-2/bax ratio, and MAPK, and exerts significant regulatory effects on cell proliferation and apoptosis [20,21]. In this study, treatment of A549 cells with metformin led to marked and concentration-based increases in the mRNA and protein expressions of $\mathrm{p}$-AMPK, and also increased the proportion of bax/bcl-2. However, it did not appreciably alter the expression level of mTOR. These results suggest that the apoptotic effect of metformin may be exerted via regulation of $\mathrm{p}$-AMPK protein expression, bax/bcl-2 ratio and ROS levels.

\section{CONCLUSION}

Metformin promotes apoptosis in A549 cells via regulation of $\mathrm{p}$-AMPK protein expression, bax/bcl-2 ratio and ROS levels, and there may be beneficial in lung cancer therapy.

Trop J Pharm Res, September 2021; 20(9): 000 


\section{DECLARATIONS}

\section{Acknowledgement}

Human Provincial Department of Education Science Research Fund, Effect of hydrogen sulfide on mitochondrial damage of myocardial cells in septic rats, (no.18C0426).

\section{Conflict of interest}

No conflict of interest is associated with this work.

\section{Contribution of authors}

We declare that this work was performed by the authors named in this article and all liabilities pertaining to claims relating to the content of this article will be borne by the authors. Xiaoli Zhang designed the study, supervised the data collection, and analyzed the data. Ziying $\mathrm{Yu}$ interpreted the data and prepared the manuscript for publication. Fengtao Liu supervised the data collection, analyzed the data and reviewed the draft of the manuscript.

\section{Open Access}

This is an Open Access article that uses a funding model which does not charge readers or their institutions for access and distributed under the terms of the Creative Commons Attribution License (http://creativecommons.org/licenses/by/ 4.0) and the Budapest Open Access Initiative (http://www.budapestopenaccessinitiative.org/rea d), which permit unrestricted use, distribution, and reproduction in any medium, provided the original work is properly credited.

\section{REFERENCES}

1. He $F$, Xiao RD, Lin T. Dietary patterns, BCMO1 polymorphisms, and primary lung cancer risk in a Han Chinese population: a case-control study in Southeast China. BMC Cancer 2018; 18 (1): 445.

2. Lally BE. Postoperative Radiotherapy for Stage II or III Non-Small-Cell Lung Cancer Using the Surveillance, Epidemiology, and End Results Database. J Clin Oncol 2016; 24(19): 2998-3006.

3. Wan G, Yu X, Chen P. Metformin therapy associated with survival benefit in lung cancer patients with diabetes. Oncotarget 2016; 7(23): 35437-35445.

4. Tian RH, Zhang YG, Wu Z. Effects of metformin on survival outcomes of lung cancer patients with type 2 diabetes mellitus: a meta-analysis. Clin Trans Oncol 2016; 18(6): 641-649.

5. Storozhuk Y, Hopmans SN, Sanli T. Metformin inhibits growth and enhances radiation response of non-small cell lung cancer (NSCLC) through ATM and AMPK. Br J Cancer 2017; 108(10): 2021-2032.

6. Herbst RS, Baas $P$, Kim DW. Pembrolizumab versus docetaxel for previously treated, PD-L1-positive, advanced non-small-cell lung cancer (KEYNOTE-010): a randomised controlled trial. Lancet 2015; 387 (10027): 1540-1550.

7. Li L, Wang Y, Peng T. Metformin restores crizotinib sensitivity in crizotinib-resistant human lung cancer cells through inhibition of IGF1-R signaling pathway. Oncotarget 2016; 7(23): 34442-34452.

8. Prabhakaran S, Thirumal D, Gimbun J. Metformin - A Panacea Pharmaceutical Agent through convergence revolution initiative. J Nat Remedies 2018; 17(3): 69-79.

9. Tian RH, Zhang YG, Wu Z. Effects of metformin on survival outcomes of lung cancer patients with type 2 diabetes mellitus: a meta-analysis. Clin Trans Oncol 2016; 18(6): 641-649.

10. Zhan S, Wang C, Yin F. MicroRNA-29c inhibits proliferation and promotes apoptosis in non-small cell lung cancer cells by targeting VEGFA. Mol Med Rep 2018; 17(5): 6705-6710.

11. Erratum: The IncRNA XIST exhibits oncogenic properties via regulation of miR-449a and Bcl-2 in human nonsmall cell lung cancer. Acta Pharmacol Sin 2017; 38 (3): 443 - 443.

12. He M, Zhu J, Yu N. The Superior Antitumor Effect of SelfAssembled Paclitaxel Nanofilaments for Lung Cancer Cells. Current Drug Delivery 2019; 16 (2): 171 - 178.

13. Li $C, W u X$, Sun $R$. Croton Tiglium Extract Induces Apoptosis via Bax/Bcl-2 Pathways in Human Lung Cancer A549 Cells. Asian Pac J Cancer Prev 2016; 17 (11): 4893 - 4898

14. Pearson HE, lida $M$, Orbuch RA. Overcoming resistance to cetuximab with honokiol, a small-molecule polyphenol. Mol Cancer Ther 2017; 17(1): 204-214.

15. Abulaiti A, Zhao ZW, Li X, Lv JQ, Wang XW, Dang JF, Ma SM. Effect of Down-Regulated Nek2 Expression of Sirna on Proliferation, Apoptosis and Radiosensitivity Of Non-Small Cell Lung Cancer A549 Cells. Acta Med Mediterr 2020; 36(5): 2869-2873.

16. Li B, Li YJ, Zhou Y, Fu DZ, Wang QY, Bu XP, Tian SH. Corosolic Acid Inhibits the Growth Of Human NonSmall-Cell Lung Cancer A549 Cells By Regulating The Vegf/Vegfr2 Signalling Pathway. Acta Med Mediterr 2019; 35(5): 2351-2356.

17. He K, Guo X, Liu Y. TUFM downregulation induces epithelial-mesenchymal transition and invasion in lung cancer cells via a mechanism involving AMPK-GSK3 $\beta$ signaling. Cell Mol Life Sci 2016; 73(10): 2105-2121.

18. Jin W, Lu S, Wang $X$, Shu Y, Shi H. Raddeanin $A$ suppresses lung cancer cell proliferation via induction of apoptosis and increased production of ROS. Cell Mol Biol (Noisy-le-grand) 2020; 66(7): 174-179.

19. Li D, Lixia Y, Fengsui L, Haitao Z, Xinwei C. Farrerol ameliorates diabetic hepatopathy in rat model of type 2 diabetes mellitus via modulation of oxidative-

Trop J Pharm Res, September 2021; 20(9): 000 
inflammatory stress. Trop J Pharm Res 2020; 19(1): 71 76.

20. Kim HI, Hong SH, Ku JM. Scutellaria Radix Promotes Apoptosis in Non-Small Cell Lung Cancer Cells via Induction of AMPK-Dependent Autophagy. Am J Chin Med 2019; 47 (3): 1-15.
21. Wu D, Wang XP, Zhang W. Sesamolin exerts antiproliferative and apoptotic effect on human colorectal cancer cells via inhibition of JAK2/STAT3 signaling pathway. Cell Mol Biol (Noisy-le-grand) 2019; 65(6): 96100. 